\title{
シンクロトロン光によるアルミニウム合金 チェンバーのガス放出*
}

\author{
金沢 健一**.百瀬 丘 ${ }^{* *}$. 小林 正典**.石丸 肇**
}

(昭和61年 1 月 6 日 受理)

\begin{abstract}
Gas Desorption from Al-alloy Chamber due to Synchrotron Radiation
Ken-ichi KANAZAWA, Takashi MOMOSE, Masanori KOBAYASHI and Hajime ISHIMARU
\end{abstract}

(National Laboratory for High Energy Physics, 1-1 Uehara,

Oho-machi, Tsukuba-gun, Ibaraki, 305)

(Received January 6, 1986)

\section{1.はじめに}

リング型の加速器では, 周回する粒子によってシンク ロトロン放射が生ずる. 粒子の全エネルギーの静止質量 に対する比 $(\gamma)$ が 1 よりはるかに大きい場合には, シン クロトロン光によるチェンバー壁面からのガス放出が加 速器の真空（真空度及びガス成分）を決める主要因とな る. 既設の加速器における経験から, シンクロトロン光 によるガス放出は, 光によるチェンバー表面の吸着ガス の脱離と考えて予想されるよりもはるかに大きく, むし ろ, チェンバーからシンクロトロン光によって生じる光 電子によるガスの脱離と考えられるに至っている1). た，シンクロトロン光の高エネルギー成分による固体内 部からの拡散の増大の可能性も指摘されている2). 一方 加速器を作る立場からは, シンクロトロン光によるガス 放出の量や種類が，チェンバーの材質や表面処理によっ てどの様に異るか, またシンクロトロン光のスペクトル やチェンバーへの入射角によって放出ガスの量はどの様 に変化するか, またサンプルを用いた実験から実際の加 速器での放出ガスをどの様に評価するか, 熱的なガス放 出や電子衝撃脱離のデータとシンクロトロン光によるガ ス放出をどう結び付けるか, 等の問題があり種々の実験 が行われている (文献は2)を参照)，それらによって分

* 昭和60年11月 7 日 第26回真空に関する連合講演会で講演 $(7 \mathrm{Aa}-6)$

** 高エネルギー物理学研究所 (茨城県筑波郡大穂町上原 1-1)
ったことも多いが，又，分らないことも多い，例えば， 現在高エネルギー物理学研究所で建設中のトリスタン加 速器（チェンバーはアルミ合金）の蓄積リング ( $\mathrm{AR})$ では, シンクロトロン光によるガス放出のビーム電流当 りの值は, ビーム電流の積分値 $(\mathrm{D})$ に関して $\mathrm{D}^{-1}$ の様 に減少しているが， PETRA では $\mathrm{D}^{-0.63}$ の様に変化して いることが報告されているし ${ }^{3)}$ ，O. Gröbner 他のアル ミ合金チェンバーのサンプル実験でも大部分 $\mathrm{D}^{-1} よ り$ 緩い4). この D依存性の違う理由はよく分っていない. 同様に現在 $\mathrm{AR}$ では放出ガス中の $\mathrm{CO}$ がビームのライ フタイムを決定しているが， $\mathrm{CO}$ がこれ以後どの様に減 少していくのかも他の実験からは予測し難い.

今回報告する実験は, 特にアルミ合金チェンバーのシ ンクロトロン光によるガス放出を, サンプルチェンバー を用いた実験により理解するために行った第 1 回目のも のである. 今回の主眼の 1 つは, 長時間にわたってガス 放出の減少の様子を見ることにあった.

\section{2. 試料及び装置}

試料はすべて特殊押出しのアルミ合金チェンバーであ る. 材質は6063S-T5，6263-T5，1070-H112の 3 種類で ある.チェンバーは内径 $47 \mathrm{~mm}$, 長さ $860 \mathrm{~mm}$ である. 試料の取扱いはFig. 1 にまとめてある. He を用いた放 電洗浄は測定装置とは別のテストベンチで荒引き後行っ た. この時放電の色に $\mathrm{He}$ の色がほとんど見られなかっ 

(1) $6063 \mathrm{~S}-\mathrm{T} 5$
(2) $6263-\mathrm{T} 5$
(3) $6263-\mathrm{T} 5$
(4) $1070-\mathrm{HI} 12$

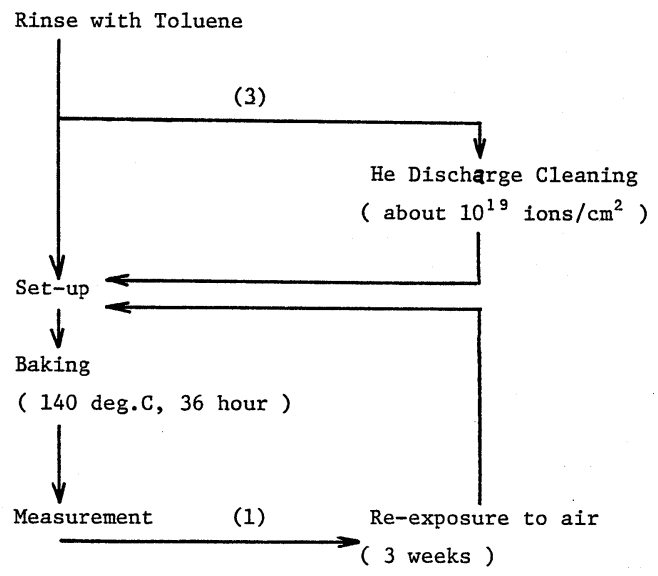

Fig. 1 試料の材質と取扱い.

たので $\mathrm{He}$ 放電洗浄という言い方が適当かどうかは疑問 である。

測定は高エネルギー物理学研究所放射光施設 (PF) で行った. 装置の主要部を Fig. 2 に示す.シンクロト ロン光は最終的に発光点から $4235 \mathrm{~mm}$ の位置のコリメ ーターで $5 \mathrm{~mm} \times 5 \mathrm{~mm}$ に絞られ, 測定室を通り試料チ エンバーを $3^{\circ}$ の入射角で照射する. この入射角の值は $\mathrm{AR}: 3,57^{\circ}$, トリスタン主リング : $1.21^{\circ}$ の中間の值を 採用した. シンクロトロン光の臨界エネルギーは $4 \mathrm{keV}$
で, チェンバーに当る光子数は単位時間, ビーム電流 1 $\mathrm{mA}$ 当り，約 $3 \times 10^{14}$ 個で，エネルギーにして約 $80 \mathrm{~mW}$ である. 光の直接当る部分は $6 \mathrm{~mm} \times 130 \mathrm{~mm}$ となる. 排気は測定室から行い測定中はイオンポンプのみを使用 した. イオンポンプの測定室に対する排気速度は特性表 から $10^{-7}$ Torr 台で $41 \mathrm{l} / \mathrm{s}\left(\mathrm{N}_{2}\right.$ 換算 $), 10^{-8}$ Torr で 36.5 $l / \mathrm{s}\left(\mathrm{N}_{2}\right.$ 換算 $)$ と与えられる. 四重極質量分析計及び $\mathrm{B}-$ A ゲージを測定室に取付け全圧及び分圧を測定した．但 し感度較正はしていない.ターボ分子ポンプを初期排気 時及びベーク時に補助的に使用した.

\section{3. 結果及び考察}

以下，我々のデータの示す特徵とそれから考えられる ことを述べる.ビーム電流当りの全圧上昇の変化を Fig. 3 に示した. 比較のために同じビーム電流の積分値 における AR のデータを示してあるが，傾向を比べる ためのものであり，この図から值を比較することは意味 がない. ベーキングのみの試料は AR に近いが, 多少 緩い減少を示している．また放電洗浄を行った試料や一 度シンクロトロン光を照射した試料では ARや上述の 試料よりもずっと緩い減少を示しているのが注目に值す る(ARはベーキングや放電洗浄は行っていない).

Fig. 4 にベーキングのみの試料における水素分圧の上昇 の変化を示した. 3 種のチェンバーともほとんど同じ值 を示していて後述の $\mathrm{CO}$ 及び $\mathrm{CO}_{2}$ の場合と著しい対照 をなしている. また変化も緩く $\mathrm{D}^{-0.5}$ に近い. Fig. 5 に ベーキングのみの試料における $\mathrm{CO}$ と $\mathrm{CO}_{2}$ の分圧上昇 （の和）の変化を示した. 水素の場合と異り, Fig. 8 に 示す様に, 初期圧力とはっきりした相関を示している.

\section{TOP VIEW}

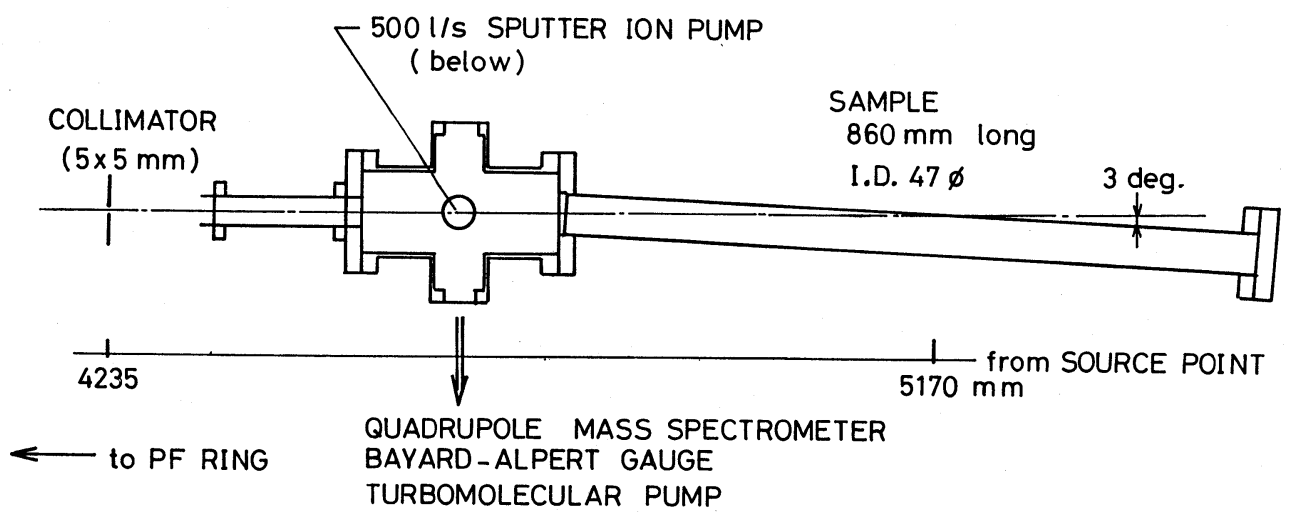

Fig. 2 測定装置主要部 


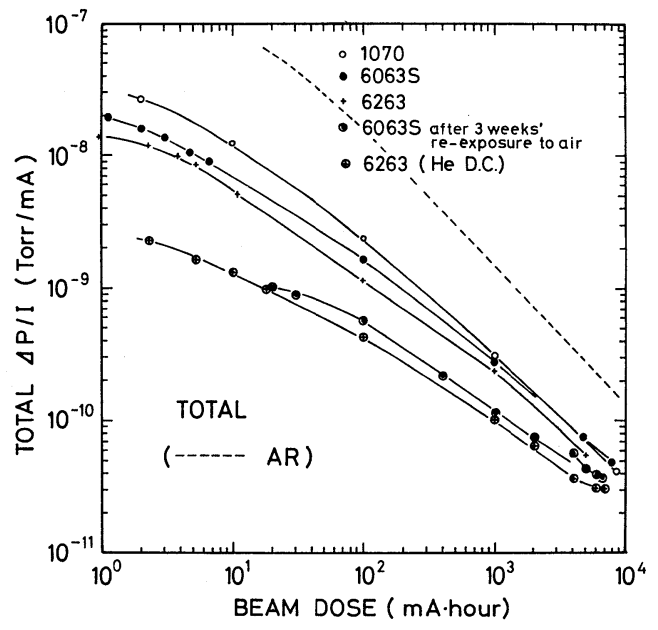

Fig. 3 ビーム電流当りの全圧上昇

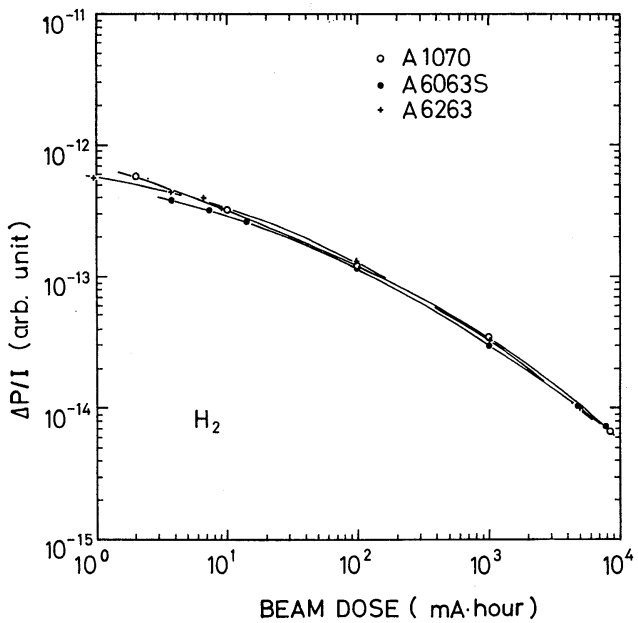

Fig. 4 ベーキング処理のみの試料のビーム電流当 りの $\mathrm{H}_{2}$ 分圧上昇

また変化も水素より急で $10^{3} \mathrm{~mA} \cdot$ hour を越す付近では $\mathrm{D}^{-1}$ の様に減少している. Fig. 6 亿放電洗浄を行った 試料(6263)と，一度シンクロトロン光を当てた後 3 週間 大気に曝し，再びシンクロトロン光を照射した場合 $(6063 \mathrm{~S})$ の水素の分圧上昇を示した. 放電洗浄によって $1 / 2$ 弱水素の分圧上昇が減っている。 また一度シンク口 トロン光を当てた試料は著しい記憶効果を示している.

Fig. 7 に Fig. 6 と同様の場合の $\mathrm{CO}+\mathrm{CO}_{2}$ の変化を示し ている. 放電洗浄の場合が一番小さい值を示していると 同時に減少のし方が緩い。しかし $\mathrm{CO}+\mathrm{CO}_{2}$ の場合はべ

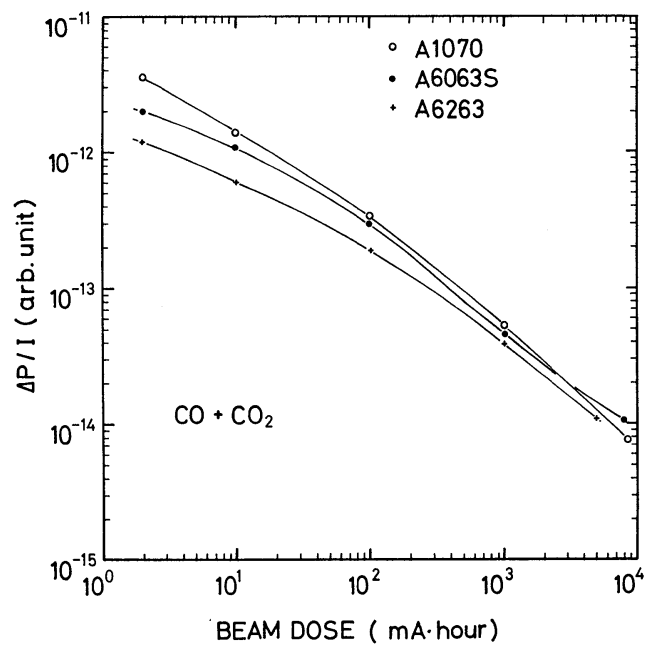

Fig. 5 ベーキング処理のみの試料のビーム電流当 りの $\mathrm{CO}$ 分圧上昇と $\mathrm{CO}_{2}$ 分圧上昇の和

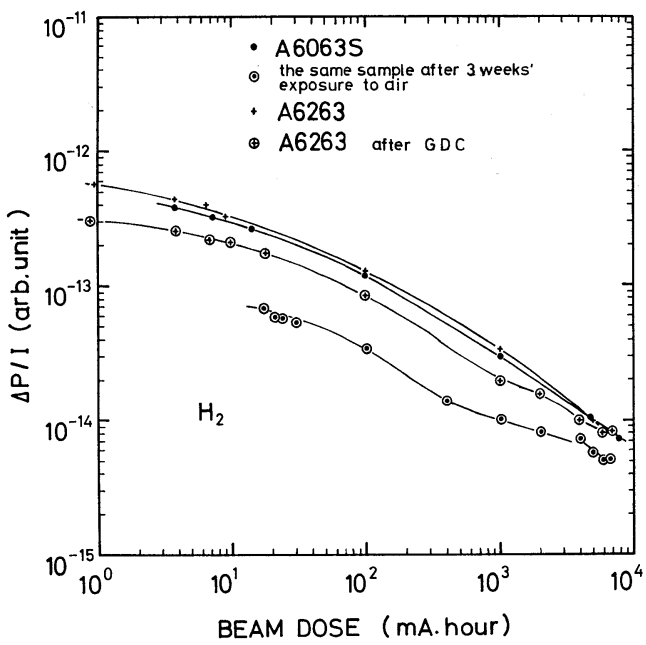

Fig. 6 放電洗浄を行った試料と、一度シンクロト ロン光を照射した試料のビーム電流当りの $\mathrm{H}_{2}$ 分圧上昇 (参考のため同質の試料のベ 一クのみの時の分压上昇を示した.）

ークのみの試料も含めてすべて分圧上昇が初期圧力 (バ ックグラウンド圧力）とよい相関を示している. 一方 $\mathrm{H}_{2}$ の分圧上昇は初期圧力と全く相関がない（Fig. 8). 尚，シンクロトロン光による分圧上昇を示したのは $\mathrm{H}_{2}$, $\mathrm{CO}, \mathrm{CO}_{2}$ 及びわずかながら $\mathrm{CH}_{4}$ であった。水は，バッ クグラウンド中に存在したが，分圧は変化しなかった。

以上の事実から次の様なことが考えられる.

シンクロトロン光によって放出する $\mathrm{H}_{2}$ は，分圧上昇 


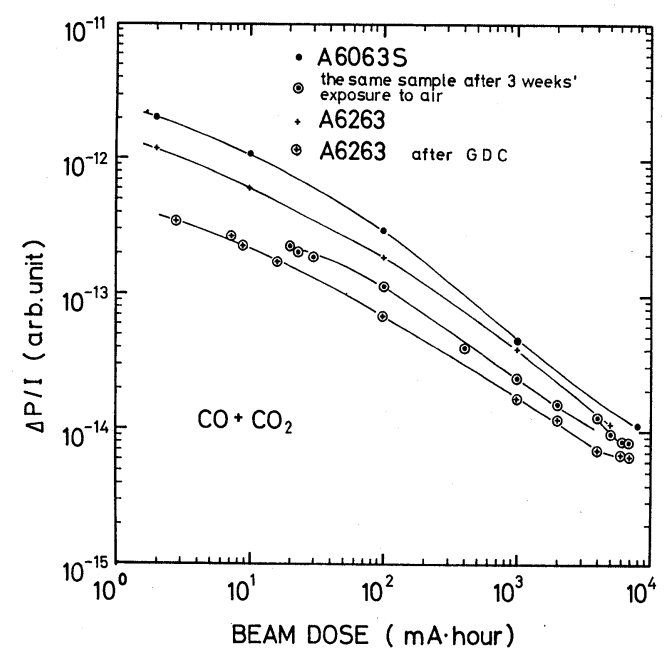

Fig. 7 放電洗浄を行った試料と, 一度シンクロト ロン光を照射した試料のビーム電流当りの $\mathrm{CO}$ 分圧上昇と $\mathrm{CO}_{2}$ 分圧上昇の和（参考の ため同質の試料のベークのみの時の分圧上 昇を示した. )

が，ベークのみの試料では試料によらないこと，全体と して初期圧力と相関がないこと，記憶効果が著しいこ と，減少のし方が緩やかで $\mathrm{D}^{-0.5}$ に近いことから，試料 内部からの拡散と考えられる。一方 $\mathrm{CO}+\mathrm{CO}_{2}$ は, 分圧 上昇が常に初期圧力と相関があること, 放電洗浄の効果 が著しいこと，減少のし方が $\mathrm{D}^{-1} に$ 近いことから，試 料表面からの（光電子による）脱離によって生じると考 えてよいと思われる.

\section{4. まとめ}

アルミ合金チェンバーの放射光による圧力測定を行っ た．放出ガスの内 $\mathrm{H}_{2}$ は，分圧上昇がベークのみの試料 では試料によらない， $\mathrm{D}^{-0.5}$ の様に減少する, 記憶効果 が著しい，等の点から内部からの拡散によって生じると 考えられる。 また $\mathrm{CO}$ や $\mathrm{CO}_{2}$ は, 分圧上昇が, 初期圧

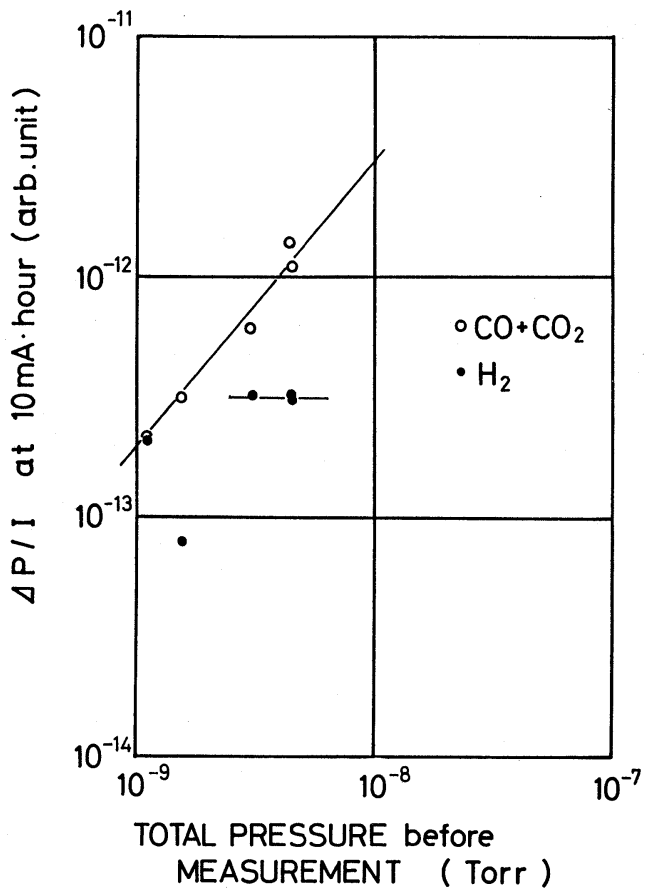

Fig. 8 分圧上昇と初期圧力との相関. 初期圧力の 低い方から，6263 (He D.C.)，6063 S（再 照射), 6263, $6063 \mathrm{~S}$ (1 回目), 1070.

力と相関がある, $\mathrm{D}^{-1}$ の様に減少する, 放電洗浄によ って著しく減少する, 等の点から表面からの脱離と考え られる.

\section{〔文献〕}

1) G. E. Fisher and R. A. Mack: J. Vac. Sci. Technol. 2 (1965) 123.

2) 小林正典 : 真空27 (1984)/解説.

3) J. S. Kouptsidis: Proc. 7th Intern. Vac. Congr. \& 3rd Intern. Conf. solid Surfaces (Vienna 1977) 341.

4) O. Gröbner, A. G. Mathewson, H. Störi, P. Strubin and R. Souchet: Vacuum 33 (1983) 397. 